\title{
Inhibin B Measurement
}

National Cancer Institute

\section{Source}

National Cancer Institute. Inhibin B Measurement. NCI Thesaurus. Code C96681.

The determination of the amount of inhibin B present in a sample. 